\title{
純鉄における酸化物によるイオウの粒界偏析と 粒界脆性破壊の抑制
}

\author{
山本広一* 井上 泰** \\ *新日本製鐵株式会社堺技術研究室 \\ **新日本製鐵株式会社技術開発本部
}

J. Japan Inst. Metals, Vol. 58, No. 8 (1994), pp. 872-881

\section{Suppression of Intergranular Brittle Fracture in Pure Iron by Reducing Grain Boundary Segregation of Sulfur with Oxides}

\author{
Kohichi Yamamoto* and Tohru Inoue** \\ ${ }^{*}$ Sakai $R \& D$ Lab., Nippon Steel Corp., Sakai \\ **Technical Development Bureau, Nippon Steel Corp., Kawasaki
}

\begin{abstract}
Studies were made of the effect of alloying elements on the grain boundary embrittlement of commercially pure iron (from electrolytic iron; C content $\sim 0.002$ mass $\%$, O content $\sim 0.015$ mass $\%$, S content $\sim 0.006$ mass $\%$ ) by Charpy tests and AES analysis of impurities at grain boundaries. Special reference was made to oxygen as oxides. It was found that the improvement of the embrittlement by the addition of $\mathrm{C}, \mathrm{Al}, \mathrm{Mn}$ and $\mathrm{Ca}$ is due to the decrease of $\mathrm{S}$ concentration at grain boundaries. As a result of the reaction with $\mathrm{Mg}$ which is a trace impurity in molten iron, $(\mathrm{Al}, \mathrm{Mg})_{x} \mathrm{O}$, possibly $\mathrm{MgO} \cdot \mathrm{Al}_{2} \mathrm{O}_{3}$ of the cation vacancy type, was formed in the specimens containing $\mathrm{Al}$. On the basis of this result, it was deduced that the diffusion of $\mathrm{Mg}$ and $\mathrm{Al}$ by cation vacancies easily occur and the preferential nucleation of $\mathrm{MgS}$ and $\mathrm{Al}(\mathrm{N}, \mathrm{S})$ on the outermost $\mathrm{MgO} \cdot \mathrm{Al}_{2} \mathrm{O}_{3}$ results in the suppression of grain boundary segregation of $\mathrm{S}$. A similar analysis were made on the effect of $\mathrm{Mn}$ and $\mathrm{Ca}$.
\end{abstract}

(Received August 11, 1993)

Keywords: intergranular brittle fracture, pure iron, sulfur, oxides, aluminium, magnesium, grain boundary segregation, cation vacancy, precipitation, toughness

\section{I. 緒言}

高純度鉄の粒界脆性破壊に関する研究は木村(1)により詳細な 報告がなされている。それルよれば，純鉄(純度 99.9 mass\%

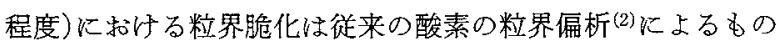
ではなく，粒界の結合力を高めるCの粒界偏析量の減少に起 因していることが明らかにされている。季た，P，Sの粒界偏 析による粒界脆化促進や B 飞上る粒界脆化抑制の效果る知方 和ている(1)(3).

一方，実用鋼に怙いては，延性，勒性，電磁特性等を向上さ せるため固溶 $\mathrm{C}, \mathrm{N}$ の低減が必要であり，これを目的に真空脱 ガス処理が高深絞り用冷延鋼板, 電磁鋼板, 建䅇用極低降伏点 鋼などに適用されている。しかし，真空脱がス処理を施した鋼 材についても，使用条件によっては，椧間加工割孔(4)，低温脆 化など材質劣化を生じる場合がある，これらの現象もまた，C

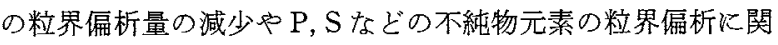
連しており，溶鉄の精錬処理による不純物除去や $\mathrm{Mn}$ 添加 ( $\mathrm{S}$ の固定)あるいは，B添加により改善されている(5).

これとは別に，最近，溶鋼中比晶出させた微細な酸化物粒子
を固相中での異相析出物の析出核として活用し，これを組織制 御招よび析出制御火利用する，オキサイドメタラジー(6)の考兄 方が提唱されている。この概念が示唆するように, 化学的に活 性な酸化物粒子を溶鉄中に分散晶出させ，この酸化物に不純物 元素を析出物として優先析出させて固定し，不純物元素を無害 化することも可能と考えられる。

このような視点から本研究では，酸素含有量が比較的多い電 解純鉄を素材とし，これに酸化物形成剂として Mn, Al, Ca, Ti を添加し微紐な酸化物粒子を晶出分散させた試料を調製し，こ れらの試料について S,Pの粒界偏析，和よびをれに関薑する 粒界脆化の樣相などを調べた。この実験結果に基づき，特に $\mathrm{S}$ の場合について，その粒界偏析が晶出酸化物粒子により抑制 されることの可能性执よびその機構について考察する.

\section{II. 実 験 方 法}

\section{1. 供試材の製造方法および化学分析值}

供試材の原料には，Table 1 の化学成分値をるつ2 種類の電 解鉄を用いた。 \#I1 は硫酸浴電解鉄, \#I2 は塩酸浴電解鉄で ある。これらの原料をそれぞれ高周波真空溶解炬によりマグネ 
Table 1 Chemical compositions of electrolytic iron materials. (mass\%)

\begin{tabular}{c|c|c|c|c|c|c|c|c|c}
\hline \hline Materials & $\mathrm{C}$ & $\mathrm{Si}$ & $\mathrm{Mn}$ & $\mathrm{P}$ & $\mathrm{S}$ & $\mathrm{A} 1$ & $\mathrm{~N}$ & $\mathrm{O}$ & $\mathrm{B}$ \\
\hline \#I1 & 0.0020 & 0.0001 & 0.0001 & 0.0003 & 0.0042 & 0.0001 & 0.0015 & 0.015 & 0.0001 \\
\#I2 & 0.0019 & 0.0001 & 0.0001 & 0.0002 & 0.0001 & 0.0001 & 0.0002 & 0.014 & 0.0001 \\
\hline
\end{tabular}

Table 2 Chemical compositions of specimens. (mass\%)

\begin{tabular}{l|c|c|c|c|c|c|c|c|c|c|c}
\hline \hline Specimens & $\mathrm{C}$ & $\mathrm{Si}$ & $\mathrm{Mn}$ & $\mathrm{P}$ & $\mathrm{S}$ & $\mathrm{Al}$ & $\mathrm{N}$ & $\mathrm{O}$ & $\mathrm{Ca}$ & $\mathrm{Ti}$ \\
\hline $2 \mathrm{C} 1$ & 0.002 & 0.002 & $<0.004$ & 0.003 & 0.006 & 0.003 & 0.0019 & 0.0097 & - & - \\
$2 \mathrm{C} 2$ & 0.002 & 0.002 & $<0.004$ & 0.004 & 0.005 & 0.001 & 0.0002 & 0.0193 & - & - \\
$2 \mathrm{CP}$ & 0.002 & 0.005 & $<0.004$ & $\underline{0.031}$ & 0.006 & 0.003 & 0.0019 & $(0.01)$ & - & - \\
$3 \mathrm{C}$ & 0.003 & 0.004 & $<0.004$ & 0.005 & 0.007 & 0.003 & 0.0018 & $(0.01)$ & - & - \\
$4 \mathrm{C} 1$ & 0.004 & 0.005 & $<0.004$ & 0.003 & 0.006 & 0.003 & 0.0019 & 0.0170 & - & - \\
$4 \mathrm{C} 2$ & 0.004 & 0.006 & $<0.004$ & 0.004 & 0.007 & 0.001 & 0.0002 & 0.0061 & - & - & - \\
$4 \mathrm{CP}$ & 0.004 & 0.005 & $<0.004$ & 0.031 & 0.006 & 0.003 & 0.0019 & $0.01)$ & - & - \\
\hline $2 \mathrm{CMnP}$ & 0.002 & 0.005 & $\underline{0.140}$ & 0.026 & 0.005 & 0.001 & 0.0004 & 0.0160 & - & - \\
$2 \mathrm{CAl1}$ & 0.002 & 0.005 & $<0.004$ & 0.004 & 0.006 & 0.250 & 0.0019 & 0.0033 & - & - \\
$2 \mathrm{CA} 12$ & 0.002 & 0.005 & $<0.004$ & 0.004 & 0.006 & $\underline{0.239}$ & 0.0002 & 0.0160 & - & - \\
$6 \mathrm{CAlP}$ & $\underline{0.006}$ & 0.005 & $<0.004$ & $\underline{0.031}$ & 0.008 & $\underline{0.228}$ & 0.0003 & 0.0130 & - & - \\
$2 \mathrm{CCaP}$ & 0.002 & 0.004 & $<0.004$ & $\underline{0.027}$ & 0.005 & 0.001 & 0.0005 & 0.0185 & $\underline{0.0002}$ & - \\
$2 \mathrm{CTiP}$ & 0.002 & 0.006 & $<0.004$ & $\underline{0.030}$ & 0.006 & 0.001 & 0.0006 & 0.0110 & - & $\underline{0.0138}$ \\
\hline
\end{tabular}

* All specimens were quenched after holding for $3.6 \mathrm{ks}$ at $1123 \mathrm{~K}$.

シアるつぼ内で溶解し，雾囲気をアルゴンガスで置換した後に， C, Mn, Al, Ca, Ti, S, P などを添加し，Table 2 に示す試料を溶 製した。鋳塊質量はそれぞれ $50 \mathrm{~kg}$ であり， Mn, $\mathrm{Al}, \mathrm{Ca}$ など の酸化物は凝固の際に晶出している. B は添加していないが, すべての試料に拈いて，化学分析值で，1 mass ppm 程度が含 有されている. $\mathrm{Mg}$ 含有量は $\mathrm{Al}$ 添加の試料 2CAl1, 2CA12 に 拈いても，溶液発光分光分析法による $\mathrm{Mg}$ の検出限界である 1 mass ppm 以下であった.

\section{2. 圧延および熱処理条件}

溶製した厚さ $100 \mathrm{~mm}$ の鋳塊を $1523 \mathrm{~K}$ にて，3.6 ks 保持し 板厚 $13 \mathrm{~mm}$ に熱間圧延したのち空冷した。熱間圧延仕上げ温 度は $\gamma$ 相温度域の $1223 \mathrm{~K}$ で一定とした。

この圧延板から圧延方向に長さ $100 \mathrm{~mm}$ の試験片を採取し, これを大気炉で $\alpha$ 温度域の $1123 \mathrm{~K}$ に加熱し $3.6 \mathrm{ks}$ の保持後, $5 \%$ 食塩水水中に浸漬急冷する熱処理を付与した．この熱処理 は $\alpha$ 温度域加熱により $\mathrm{S}, \mathrm{P}$ などの不純物元素を $\alpha$ 粒界に偏析 させるために行った。

\section{3. 勒性測定と破面観察}

熱処理材から圧延方向に加工採取した $2 \mathrm{mmVノッチシャル}$ ピー試験片についてシャルピー試験を行い, 求めた破面遷移温 度(FATT)により勒性を評価した。破面様式と粒界破面率はシ ヤルピー試験片破面の走查型電子顕微鏡 $(\mathrm{SEM})$ 観察により測 定した。測定視野数は 100 倍 $\left(85 \mathrm{~mm} \times 75 \mathrm{~mm}^{2}\right)$ で10視野とし た.

\section{AES による粒界偏析測定}

(1) AES 試験片は長さ $30 \mathrm{~mm}$, 直径 $3.4 \mathrm{~mm}$ とし, その中 央部に $0.5 \mathrm{~mm}$ 深さのノッチ加工を施した。この試験片を AES 装置内に装備された試験破断治具飞装着し, この治具を
外部から循環液体窒素で冷却し, 試験片が拉よそ $113 \mathrm{~K}$ まで 冷却された時点で，衝撃を加えて試験片を脆性破壊させ，その 粒界破面を AESにより分析した。この衝撃破断で粒界破壊し なかった試料 4C1 拈よび $2 \mathrm{CAl1}$ については，水素脆性を利用 し粒界破壊を起こさせるため，あらかじめ AES 試験片に電解 水素チャージ処理を施した．水素チャージは $3 \% \mathrm{NaCl}$ 水溶液 中で試験片を陰極にして，0.25 mA/mm² で行い, その後の水素放出を抑制するために直ちに Niメッキ を施した。

$\mathrm{AES}$ 分析測定数は $4 \mathrm{C} 1$ と $2 \mathrm{CAl1}$ については粒界破面が少 ないため各 5 箇所，その他の試料では10箇所とした.

(2) 粒界破面の偏析元素の AES 測定条件は, 真空度 1.5 $\times 10^{-8} \mathrm{~Pa}$ ，加速電圧 $8.0 \times 10^{-16} \mathrm{~J}(5 \mathrm{keV})$ ， ビーム電流 6.5 $\times 10^{-8} \mathrm{~A}$ とした．粒界破面の深さ方向の濃度変化は破面を Ar スパッタリングし AES 分析することにより調べた。その 条件は $\mathrm{Ar}$ ガス圧 : $3.8 \times 10^{-3} \mathrm{~Pa}$ で加速電圧 : $1.6 \times 10^{-16} \mathrm{~J}(1$ $\mathrm{keV})$, 試料電流 : $20 \mathrm{~mA}$ である. 粒界偏析した元素の濃度は AES ピーク高さと相対感度係数から算出し(7), それらの平均 值で表記した.

（3）加熱による元素の表面偏析挙動は $10 \mathrm{~mm}$ 角, $2 \mathrm{~mm}$ 厚 のバフ研磨した試験片をAES 装置内で電子線照射し $773 \mathrm{~K}$ に 加熱, $60 \mathrm{~s} \sim 1.8 \mathrm{ks}$ の間保持しながら, 加熱表面の元素濃度を AES で分析し，その濃度の経時変化を調べた。試験片の表面 温度は，輻射温度計を用い測定した。

\section{5. 析出物の同定}

析出物の組成拉よび粒子の分散状態は検鏡試料の $1 \mathrm{~mm}^{2}$ の 領域をX 線マイクロアナライザー(EPMA) により 2 視野を 測定して調べた．微小な析出物の同定は，検鏡試料を有機溶媒 液中で電解腐食し析出物を露呈させた抽出レプリカを用意し, エネルギー分散 $\mathrm{X}$ 線分光 $(\mathrm{EDX})$ を装備した透過型電子顕微鏡 
(TEM)により行った。な特， $\mathrm{Al}$ 添加の試料 $2 \mathrm{CAl} 2$ について は, $0.1 \mu \mathrm{m}$ 程度の微小領域の分析が可能な高分解能 AES 装 置を用い，酸化物之文の酸化物上に析出した微小析出物を分析 した。

\section{III. 実 験 結 果}

\section{1. 破面遷移温度に及ばす添加元素の影響}

破面遷移温度(FATT)に及ぼすCとPの影響をFig.1 亿示 す．C量の増加により FATTは低下するが，P量の多い場合 はその低下幅は小さい。

脱酸力の強い $\mathrm{Mn}, \mathrm{Al}, \mathrm{Ca}, \mathrm{Ti}$ の添加により, Fig. 2 飞示す ようにFATT は䫓著に低下する，特に Ca の場合は, 2 mass $\mathrm{ppm}$ の微量添加 $(2 \mathrm{CCaP})$ にもかわらず, FATTは $313 \mathrm{~K}$ まで

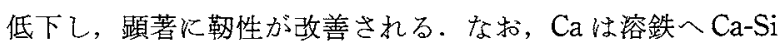
合金を用い添加したが，この方法では，Ca 添加量は 2 mass ppm が限界であった。

0.25 mass\%の Al 添加(2CAl1)により FATTは $233 \mathrm{~K}$ まで 低下する。この理由を明らかにするために，シャルピー試験で 㴔性破壊させた試料の破壊様式をSEM 観察した. Fig. 3 はそ の典型例であり，FATTが最も高い試料 2C2 は, Fig. 3(a)に 見られるように，粒界破面率が $100 \%$ でる。一方，FATTが 最多低い AI 添加した試料 2CA12 の破面(Fig. 3(b)) Kは，粒 界破面は僅かしかみられず，ほぼ全面がへき開破壊を呈してい る.これらの破面から粒界破面率を求め，FATTとの関係を 調べた。Fig. 4 亿示す上らに，粒界破面率の増加に伴い FATTが上昇する傾向がみられる.

FATTは $\alpha$ 粒径伈も影響されるので図中に $\alpha$ 粒径を付記し た. 粒界破面率とFATT とが直線関係にある試料の $\alpha$ 粒径は ほぼ同一であるが，粒界破面率が $0 \%$ 近傍の試料について，直

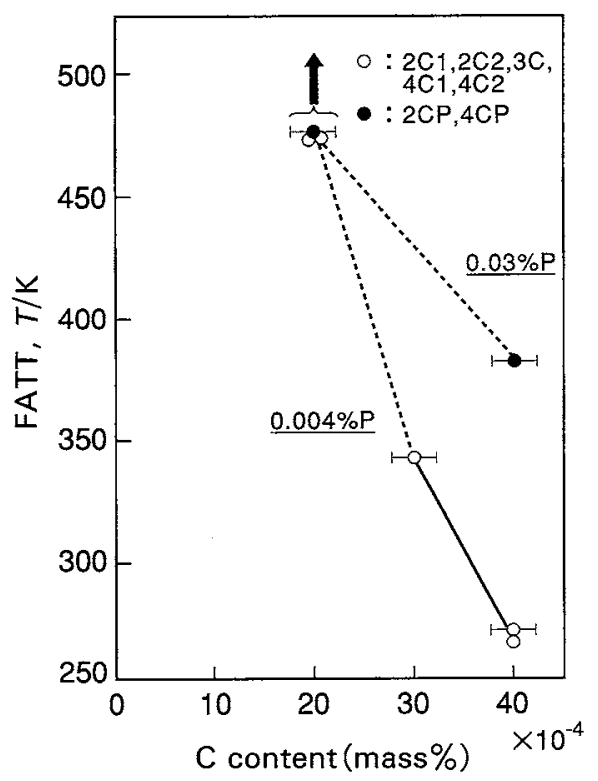

Fig. 1 Effect of $\mathrm{C}$ and $\mathrm{P}$ contents on fracture appearance transition temperature (FATT $(\mathrm{K})$ ), specimens: 2C1, $2 \mathrm{C} 2,3 \mathrm{C}, 4 \mathrm{C} 1$ and $4 \mathrm{C} 2$ contain 0.004 mass $\% \mathrm{P}(\mathrm{O})$, and $2 \mathrm{CP}$ and $4 \mathrm{CP}, 0.030$ mass $\% \mathrm{P}(\mathbf{O})$.

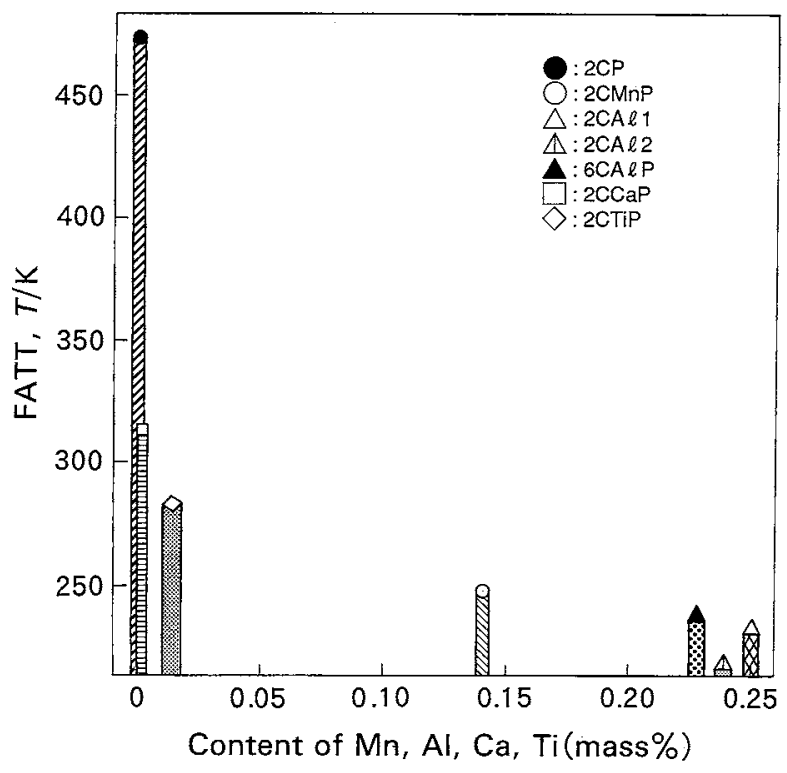

Fig. 2 Effect of $\mathrm{Mn}, \mathrm{Al}, \mathrm{Ca}$ and Ti contents on FATT (K).

線の上方にはずれた試料 $4 \mathrm{C} 2$ の $\alpha$ 粒径は $1.7 \mathrm{~mm}$ と粗粒であ り，下方にはずれた $\mathrm{Al}$ 添加の試料 $2 \mathrm{CAl} 2$ は $56 \mu \mathrm{m}$ と細粒で ある。つまり， $\alpha$ 粒径が小さい汪どFATTが低下し勒性が向 上する傾向はここでも認められる.しかし，試料 4C2 より粒 径の小さい $410 \mu \mathrm{m}$ の場合に FATT が著しく高い場合もあり, Fig. 3 の直線関係部分的含めて粒径以外の要因，つ告り不純物 元素によって粒界脆化が支配されていると考光られる。

\section{2. 粒界偏析に及ばす添加元素の影響}

Fig. 5 K, FATT が $473 \mathrm{~K}$ と高い 0.002 mass\%Cの試料 $2 \mathrm{C} 1$ ，および FATT が $233 \mathrm{~K}$ と低い $\mathrm{Al}$ 添加の試料 $2 \mathrm{CAl1}$ の 粒界破面の AES スペクトルの一例を示す．試料 $2 \mathrm{C} 1$ の粒界破 面にはSの高い濃度を示すAESピークとCとNのピークが 検出された。 S 濃度をAES ピーク高さと元素間のAES 相対 感度係数(7)から算出すると，去の濃度は 5.7 at.\%にる達して いる. 一方, Al 添加試料 2CAl1 の粒界破面のS ピーク高さは

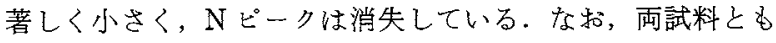
に多量の酸素を含有しているにるかかわらず，粒界破面の酸素 ピーク高さは極めて小さいことがわかる。

同様の方法でCを添加した試料やこれらにPを添加した試 料についてむ粒界破面を AES 分析した。な拉，粒界のS，C， $\mathrm{P}, \mathrm{N}$ 濃度は $\mathrm{Ar}$ スパッタリングにより粒界面から深さ方向に急 激に減少し，これらの元素が消失する深さは拉よそ $1 \mathrm{~nm}$ であ ったので前記の濃化を粒界偏析と見なした。

Fig. 6 には，C量に対して粒界偏析 S, C, N の濃度がどのよ らに変化するかを示す. C 0 $0.002 か ら 0.004$ mass\%への増加 により，粒界 C 濃度は 8.8 at.\%から13.3 at.\%に增加する。こ れに対して，粒界 S 濃度は 5.7 at.\%から 2.6 at.\%に低減する。 一方, C が 0.002 mass \%でも， $\mathrm{Al}$ 添加(2CAl1) 飞より粒界 $\mathrm{S}$ 濃度は著しく低減し 1.0 at.\%になる。また， $\mathrm{Al}$ 添加試料での 粒界 C 濃度は 10.5 at.\%であり，C 量 0.002 mass\%(2C1)の試 

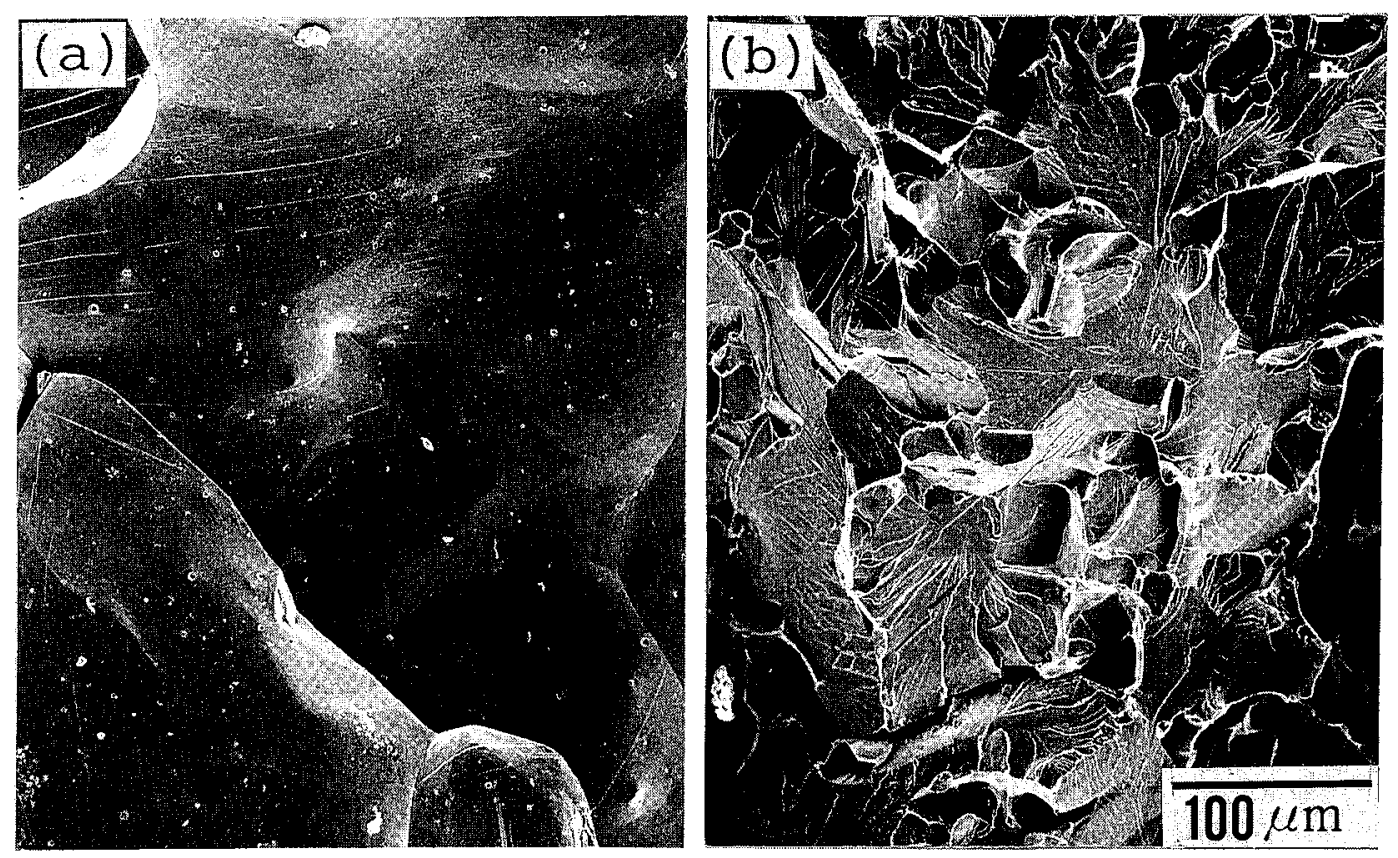

Fig. 3 Scanning electron micrograph of fractured surface of Charpy tests specimens. (a): specimen 2C2, (b): specimen 2CA12.

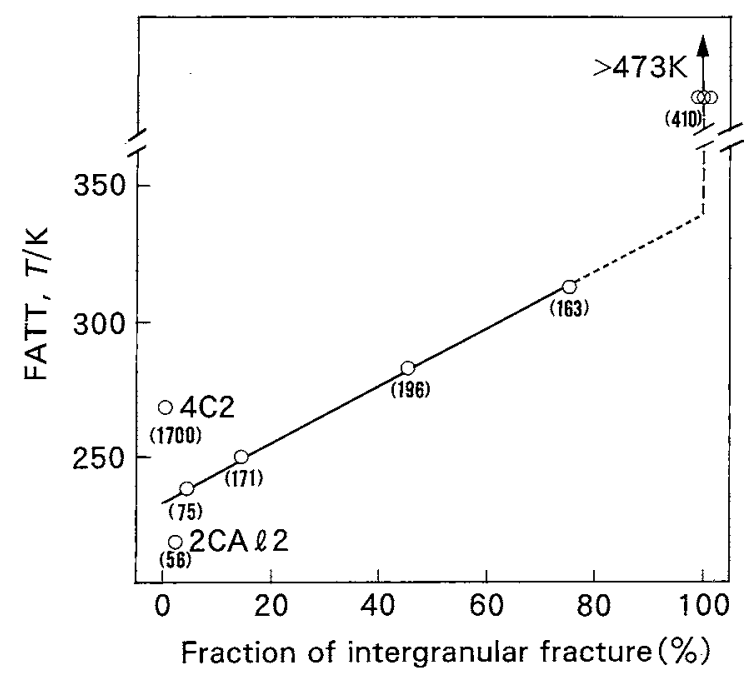

Fig. 4 Relationship between FATT (K) and fraction of intergranular fracture (\%), specimens: $2 \mathrm{C} 1,2 \mathrm{C} 2,2 \mathrm{CP}$, $4 \mathrm{C} 2,2 \mathrm{CMnP}, 2 \mathrm{CAl} 2,6 \mathrm{CAIP}, 2 \mathrm{CCaP}$ and $2 \mathrm{CTiP}$. Grain size $(\mu \mathrm{m})$ of $\alpha$-phase is shown at the each point.

料での粒界 C 濃度は 8.8 at.\%であるから, Al 添加により粒界 C 濃度は 2 at.\%ほど増加したことになる。注目すべき点は， $\mathrm{Al}$ 添加試料 (2CA11) ではN $\mathrm{N}$ 粒界偏析は皆無となり, 試料の B 含有量が 1 mass ppm と微量であるともかかわらず, 1.3 at.\%の Bのピークが認められることである.他の試料の粒界 には，B倹出されていない。

Fig. 7, Fig. 8 には粒界 S, C 濃度と FATT との関係を示す. FATT は粒界 S 濃度の增加に伴い単調に上昇する傾向を示す が(Fig. 7), 粒界 C 濃度との相関は認め難い(Fig. 8). FATT

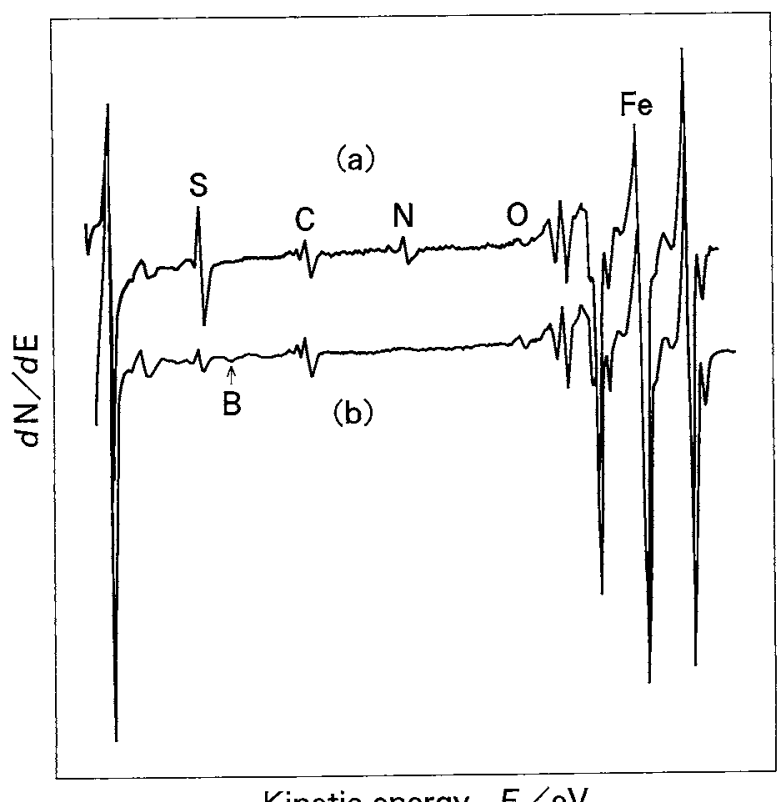

Fig. 5 AES spectra from intergranular fractured surface for specimens $2 \mathrm{C} 1$ (a) and 2CAl1 (b).

を支配する要因は主にSの粒界偏析にあるものと推察される。 な括，Al添加以外の試料の粒界には $\mathrm{N}$ る偏析している。し かし，本研究で用いた試料に扣いては $\mathrm{N}$ 含有量を約 20 mass $\mathrm{ppm}$ (試料 $2 \mathrm{C} 1,4 \mathrm{C} 1$ ) か 52 mass ppm(試料 $2 \mathrm{C} 2,4 \mathrm{C} 2$ ) に低減 してもFATTの変化は極く価かであることから，粒界偏析 N による脆化は生じないものと考えられる. 


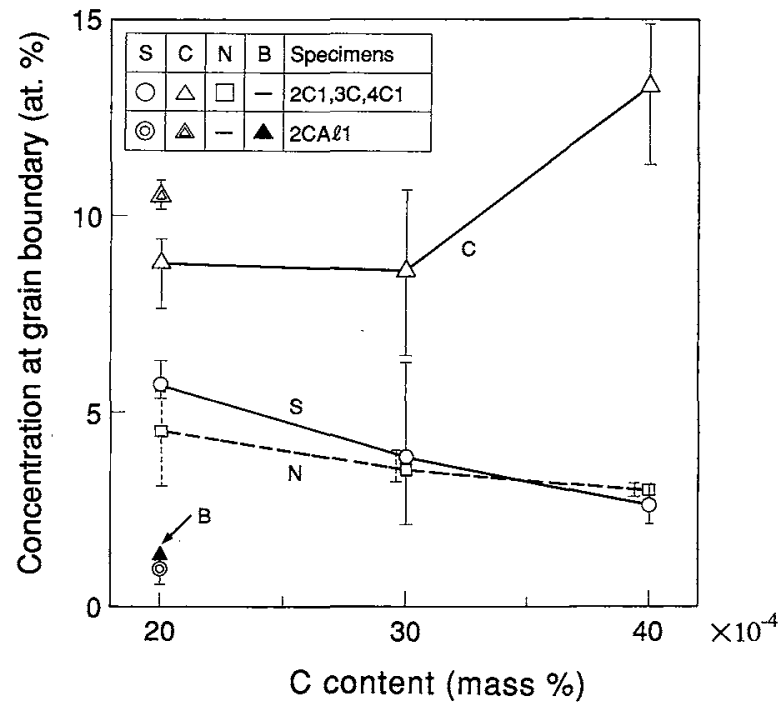

Fig. 6 Effect of addition of $\mathrm{C}$ and $\mathrm{Al}$ on the concentration of each element (S, C, N, B) at grain boundaries, specimens: $2 \mathrm{Cl}, 3 \mathrm{C}, 4 \mathrm{Cl}$ and $2 \mathrm{CAll}$.

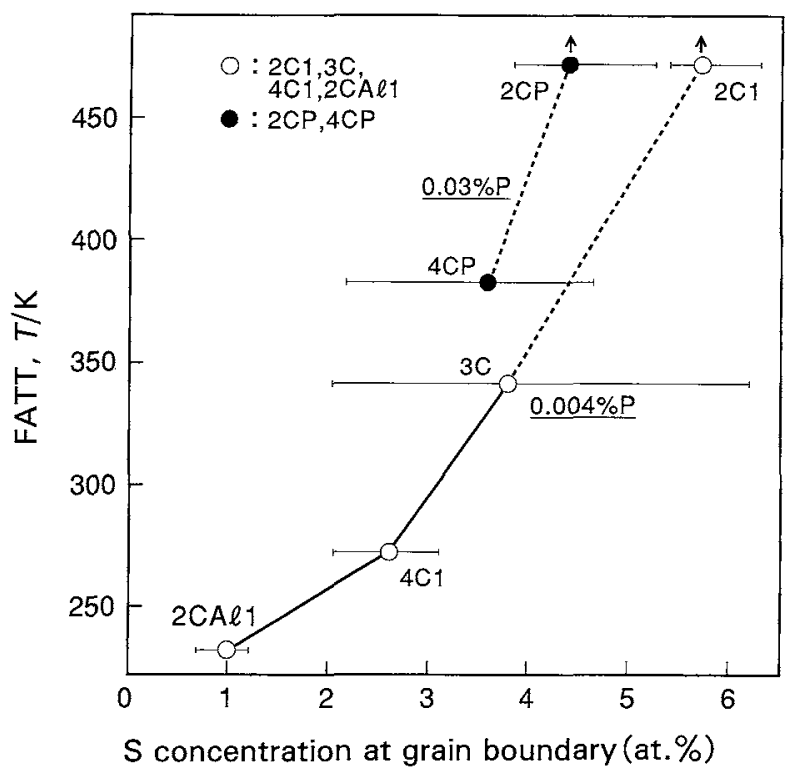

Fig. 7 Relationship between FATT $(\mathrm{K})$ and the concentration of $\mathrm{S}$ at grain boundaries, specimens: $2 \mathrm{C} 1,3 \mathrm{C}, 4 \mathrm{C} 1$ and $2 \mathrm{CAll}$ contain 0.004 mass $\% \mathrm{P}(\mathrm{O})$, and $2 \mathrm{CP}$ and $4 \mathrm{CP}$, 0.030 mass $\% \mathrm{P}(\mathbf{O})$.

\section{3. 析出物の分散状態亡結晶構造解析}

脱酸元素の $\mathrm{Mn}, \mathrm{Al}, \mathrm{Ca}, \mathrm{Ti}$ 添加比よる勒性向上効果は添加元 素により生成する酸化物敊よび硫化物に起因するもの之考充ら れる，そこで，これらの酸化物，析出物の組成とその粒子の分 布形態をEPMA と高分解能AES飞より，をた結晶構造を TEM 観察により調べた。

EPMA の元素像から測定した酸化物などの粒子の分散個数 をFig. 9 飞示す。C量を 0.002 mass\% $\%$ (試料 $2 \mathrm{C} 2$ ) から， $0.004 \mathrm{mass} \% \mathrm{C}(4 \mathrm{C} 2)$ k増加させると粒子の個数は減少する。

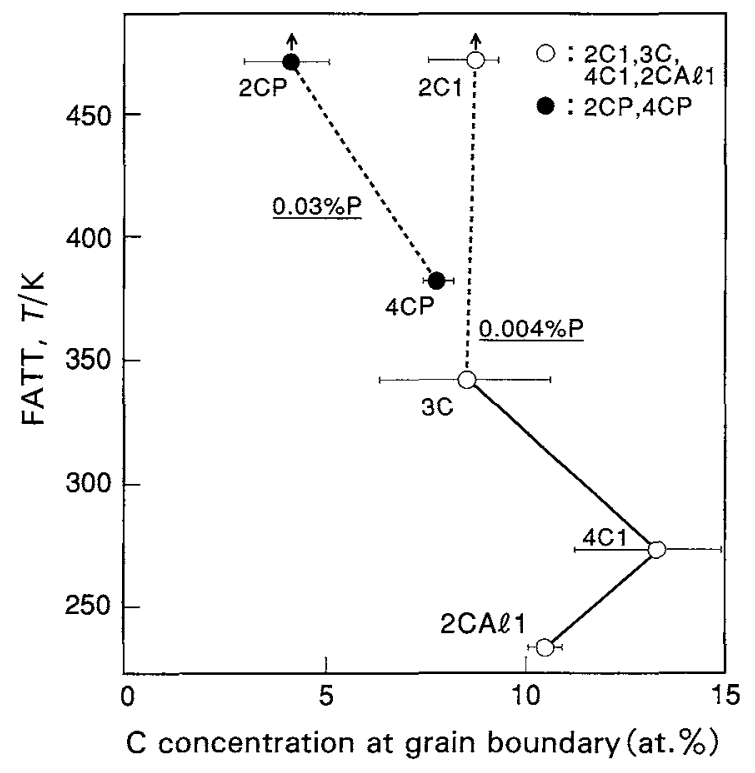

Fig. 8 Relationship between FATT (K) and the concentration of $\mathrm{C}$ at grain boundaries, specimens: $2 \mathrm{C} 1,3 \mathrm{C}, 4 \mathrm{C} 1$ and $2 \mathrm{CAl1}$ contain 0.004 mass\% $\mathrm{P}(\mathrm{O})$, and $2 \mathrm{CP}$ and $4 \mathrm{CP}$, 0.030 mass $\% \mathrm{P}$

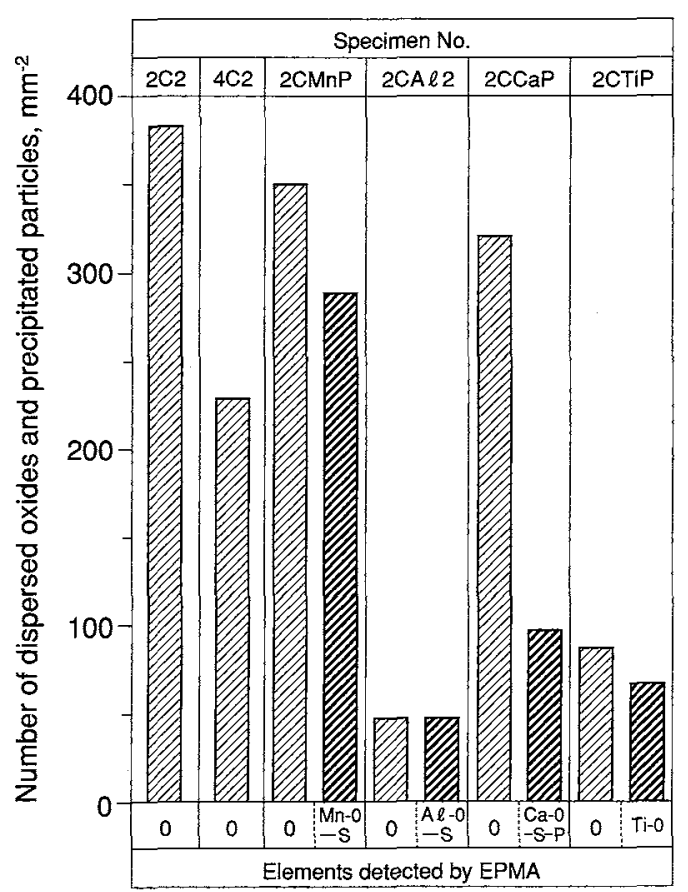

Fig. 9 Effect of $\mathrm{C}, \mathrm{Mn}, \mathrm{Al}, \mathrm{Ca}$ and Ti addition on the number of dispersed oxides and precipitated particles measured by EPMA.

この酸化物は電子線回折から FeO と同定され，10個に 1 個程 度の頻度で $\mathrm{FeO}$ 内から $\mathrm{Si}$ ( $\mathrm{Si}$ 酸化物)， $\mathrm{Al}$ ( $\mathrm{Al}$ 酸化物) とが検 出された。電解鉄を素材として真空溶解した場合，この $\mathrm{Si}$ と $\mathrm{Al}$ 量は電解鉄の含有量より1桁増加して招り，これらはるつ 


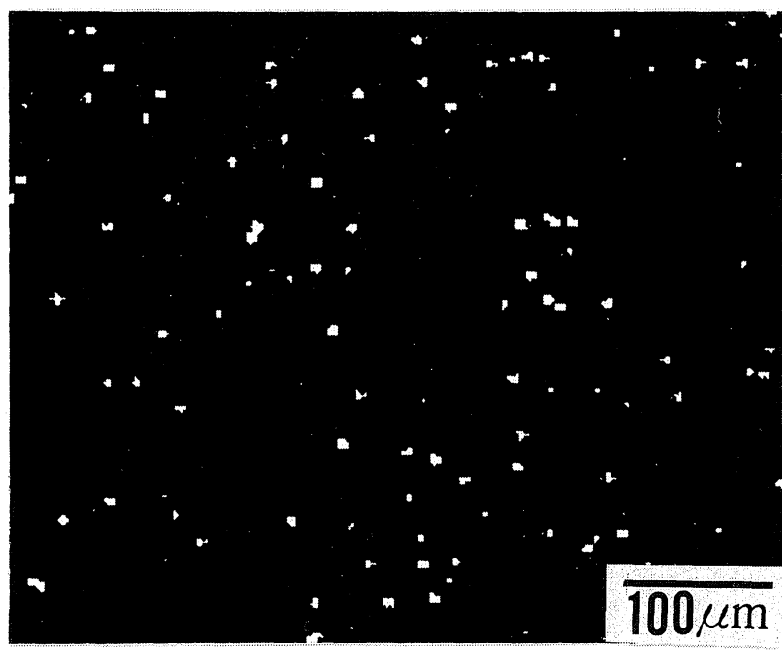

Fig. 10 EPMA image of oxygen $(\mathrm{FeO})$ in specimen $2 \mathrm{C} 2$.
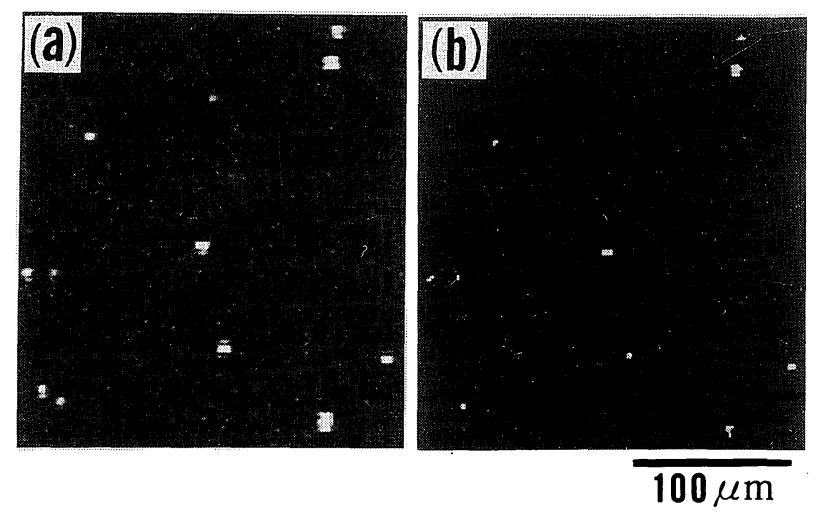

Fig. 11 EPMA images of $\mathrm{Al}$ (a) and $\mathrm{S}(\mathrm{b})$ in the same field of specimen $2 \mathrm{CA} 12$.

ぼから混入したものと考学られる。なお，EPMA 測定により 得られた酸素像(酸化物粒子)の分布は Fig. 10 扣よび Fig. 11 に示すよらに一様に分散している. 他の試料に招いても，酸化 物は固相析出ではなく溶鉄中か凝固時に晶出する場合に見られ る一様分散, 分布形態であった。

$\mathrm{Mn}$ を添加した試料 $2 \mathrm{CMnP}$ では $\mathrm{MnO}$ (酸素像) とみられる ほとんどの粒子が Mn-O-S 複合体として存在することを示唆 する EPMA 像が得られている. Mn と S 像が合致した単独の $\mathrm{MnS}$ に相当寸る像は検出されなかった.

$\mathrm{Al}$ 添加の試料 $2 \mathrm{CA} 12$ の場合には, $\mathrm{Al}$ 酸化物粒子数は極端 に低下し，そのほとんどが Al-O-S 複合体として存在すること を示唆する EPMA 像が得られている. Fig. 11 は同一視野の $\mathrm{Al}$ と $\mathrm{S}$ のPMA 像である. 例外的に $\mathrm{Al}$ 単独の粒子が認めら れるが，Fig. 9 に示したように粒子から検出される $\mathrm{Al}, \mathrm{O}, \mathrm{S}$ の像は汪とんど合致して扣り $\mathrm{Al}$ 酸・硫化物の形成を示唆して いる.な拉， $\mathrm{Al}$ 添加により晶出した粗大な $\mathrm{Al}_{2} \mathrm{O}_{3}$ は溶製過程 で浮上分離されたものとみられる。

この Al-O-S 複合体粒子を高分解能 AES により分析した結
果をFig. 12 に示す. 中心部の $\mathrm{Al}$ 酸化物には $\mathrm{Mg}$ が検出され (Fig. 12，(a)-1)，その粒子の外周上には $0.1 \mu \mathrm{m}$ 幅で $\mathrm{S}$ 濃度の 高い領域が存在し, 硫化物と判断される(Fig. 12, (a)-2). こ の部位からは $\mathrm{S}$ の他に $\mathrm{Mg}$ 扤よび $\mathrm{N}$ が検出される．また，別 の視野の $\mathrm{Al}$ 酸化物の外周上には $\mathrm{N}$ 濃度の高い領域が存在し, この部位からは $\mathrm{S}$ も検出され, $\mathrm{Al}$ 窒化物・硫化物の複合体之 考光られる(Fig. 12，(b)). な拉，この析出物の $\mathrm{Al} の \mathrm{AES} ヒ ゚$ 一ク形状は $\mathrm{Al}$ 酸化物からのそれとは明らかに異なっている.

つぎに, $\mathrm{Al}, \mathrm{Mg}, \mathrm{O}$ と $\mathrm{S}$ が検出された複合析出物について TEM 観察を行い, 電子線回折により結晶構造を同定した.

Fig. 13 に示すように，析出物の中央部は $\mathrm{Al}$ を主成分とした $\mathrm{Mg}$ を含む複合酸化物であり，たとえば $(\mathrm{Al}, \mathrm{Mg})_{\mathrm{x}} \mathrm{O}$ と表記で きる. この粒子上の微細析出物は面心立方で, その格子定数, $a=0.52 \mathrm{~nm}$ の MgS(JCPDS カード35-730)であることが明ら かになり，この硫化物の析出により $\mathrm{S}$ の粒界偏析が抑制され た可能性がある．ただし，( $\mathrm{Al}, \mathrm{Mg})_{\mathrm{x}} \mathrm{O}$ についてはその結晶構 造は同定できなかった．また，他の $(\mathrm{Al}, \mathrm{Mg})_{\mathrm{x}} \mathrm{O}$ 粒子上で検出 された $\mathrm{N}$ と $\mathrm{Al}$ 敊よび S からなる析出物 (Fig. 12(b))について も同定できなかったので, 単に $\mathrm{Al}(\mathrm{N}, \mathrm{S})$ と表記することにす る.

$\mathrm{Ca}$ 添加試料 $2 \mathrm{CCaP}$ の酸化物粒子数は多い。これらのなか で粒子数は少ないが, $\mathrm{Ca}, \mathrm{O}, \mathrm{S}, \mathrm{P}$ 像が合致した EPMA 像が得 られる粒子が存在する。これは Ca-O-S-P の複合体の存在を示 唆するものであり, この粒子について, 抽出レプリカを作製し TEM 観察を行った. しかし，P の存在は確認できなかった. これがカルシウムリン化物である場合は，水と反応し易いため 抽出レプリカ作製過程の電解抽出中に分解消失したものと考兄 られる。

\section{4. $\mathrm{S}$ の表面偏析に及ぼす $\mathrm{Al}$ の影響}

$\mathrm{Al}$ 添加による S の粒界偏析の抑制効果を明らかにする目的 で, AES 装置内で試料を $773 \mathrm{~K}$ に加熱保持しながら, 試料表 面に偏析する元素を AES 分析した. Fig. 14 に示すように, 試料 $2 \mathrm{C} 2$ に招いては, 保持時間に対し S 濃度は急峻に増加し 飽和するが， $\mathrm{Al}$ 添加試料 $2 \mathrm{CAl} 2$ では，まず $\mathrm{P} か ゙$ 偏析し，時間 の経過とともに S が緩やかに濃化する．このS の飽和濃度は 試料 $2 \mathrm{C} 2$ に比べ半減している. この違いは, $\mathrm{Al}$ 添加により固 溶 S が固定され，S の表面への拡散が明らかに抑制されたこ とを示している。な拈，Cと $\mathrm{N}$ の表面偏析濃度は両試料とも に 3 at.\%以下であり，加熱保持中の増加も見られなかった。

\section{N. 考察}

超高純度の鉄に执いて, 酸素の粒界偏析による粒界脆化は小 さいことが木村(1)により実証されている. 本研究で用いた酸素 濃度の高い電解鉄べースの純鉄に抋いても，粒界に検出される 酸素は少なく(Fig. 5)，粒界破壊の主因は酸素ではないこと， $\mathrm{S}$ の粒界偏析濃度とシャルピー試験によるFATT との相関か ら, 純鉄に微量含まれているS の粒界偏析が粒界脆化の主因 であることが明らかになった(Fig. 7). 粒界偏析 S は C 执よび $\mathrm{Al}$ の添加により低減し，これにより FATTが低下する。ま た, 硫化物生成元素でもある脱酸元素 $\mathrm{Mn}, \mathrm{Ca}, \mathrm{Ti}$ の微量添加 

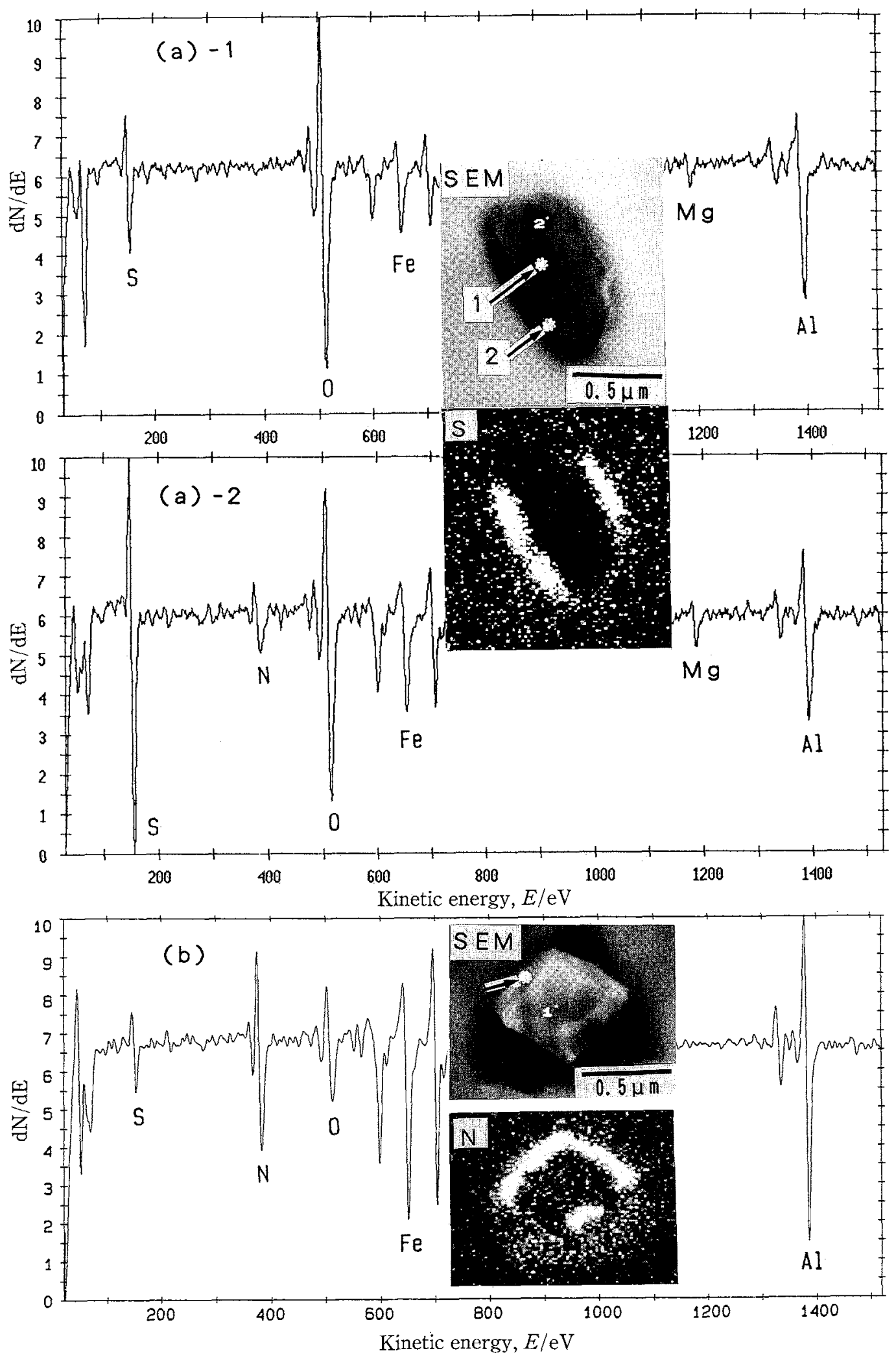

Fig. 12 High resolution AES spectra from sulfides and nitride-sulfides on Al-oxide. S, N; AES image of S and $\mathrm{N}$ on Aloxide. 

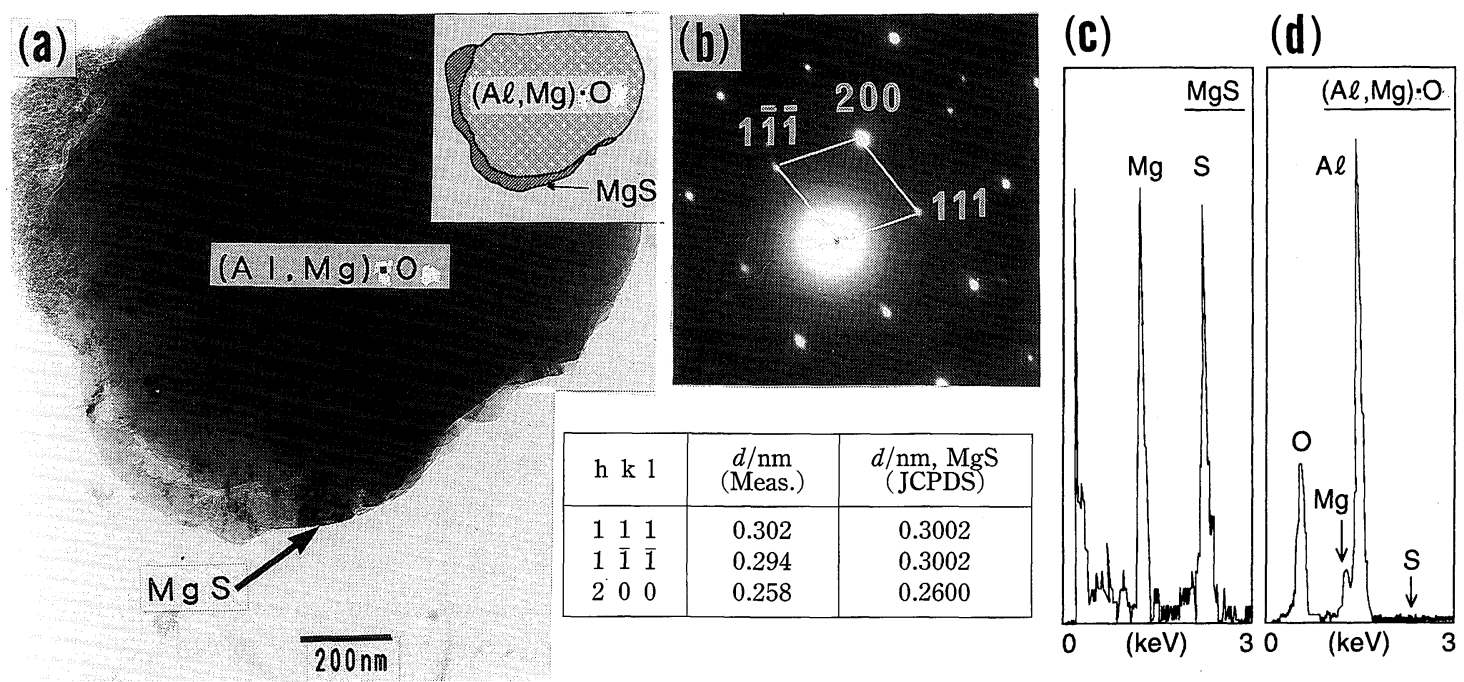

Fig. 13 Electron micrograph of precipitates of $\mathrm{MgS}$ on $(\mathrm{Al}, \mathrm{Mg}) \cdot \mathrm{O}$ in specimen $2 \mathrm{CA1} 2$ by extraction replica (a), electron diffraction pattern on $\mathrm{MgS}$ (b), EDX of $\mathrm{MgS}(\mathrm{c})$ and $(\mathrm{Al}, \mathrm{Mg}) \cdot \mathrm{O}$ (d).

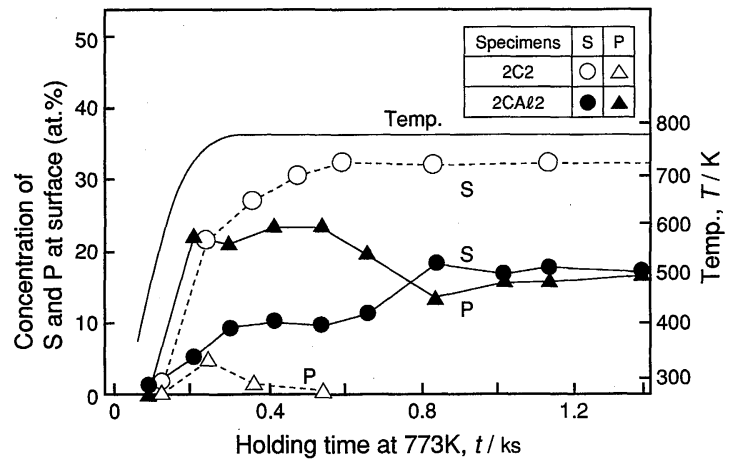

Fig. 14 Effect of $\mathrm{Al}$ addition on the segregation behavior of $\mathrm{S}$ and $\mathrm{P}$ to the surface at $773 \mathrm{~K}$ observed by AES.

によりFATT が大幅に低下し勒性が向上する結果も得られた (Fig. 2). C, Al は鉄中に抽いて, 硫化物を生成しにくいので, 単純に硫化物の生成により固溶 S が低減し, 粒界偏析が減少 するとの考学では統一的な説明はできない，この場合，電解鉄 に多量含まれている酸素により生成する酸化物粒子が硫化物の 優先核生成サイトとして機能し，この析出により固溶 S が減 少し, S の粒界偏析が抑制されるものと考学られる。このよう な視点から, 特に粒界偏析元素 $\mathrm{S}$ に焦点を絞って以下に考察 を進める。

\section{1. $\mathrm{Al}$ 系酸化物による $\mathrm{S}$ の粒界偏析抑制}

純鉄の粒界脆化が $\mathrm{Al}$ 添加により抑制されるのは, $\mathrm{Al}$ が酸化 物を生成し，固溶酸素を固定するためと考学られていた ${ }^{(8)}$.の ちに, Jolly と Goux ${ }^{(2)}$ はこの粒界脆化はSに起因しているこ と， S による粒界脆化は $\mathrm{Al}$ 添加により防止されることを報告 しているが，その機構については明らかにされていない。これ に対し本研究により, $\mathrm{Al}$ 添加の効果は S の粒界偏析の抑制に 起因していることが明らかになった(Fig. 6). また，Al 添加試
料では, AES 装置内での加熱実験に括いて, S の表面偏析が 抑制されることが確認された

$\mathrm{Al}$ の硫化物が容易に析出できるならば，一種の scavenging 効果として粒界脆化抑制の説明は容易である. Al は強力な脱 酸剤であり $\mathrm{Al}_{2} \mathrm{O}_{3}$ として酸素を固定する．また， $\mathrm{S}$ を固定する 硫化物としての $\mathrm{Al}_{2} \mathrm{~S}_{3}$ の存在も報告されている(9). これに対 し, 本研究では, $\mathrm{Al}$ 添加試料の TEM 観察招よび高分解能 $\mathrm{AES}$ とり $(\mathrm{Al}, \mathrm{Mg})_{\mathrm{x}} \mathrm{O}$ 上に大きさ0.1 0.3 $\mu \mathrm{m}$ の $\mathrm{MgS}$ と $\mathrm{Al}(\mathrm{N}, \mathrm{S})$ が析出していることを確認した(Fig. 12, Fig. 13). また， EPMA 測定においても $\mathrm{Al}, \mathrm{O}, \mathrm{S}$ が高い頻度で重盢し, Al-O-S 複合体の存在を示した Fig. 9)。これらの結果は, 粒 内に分布した $(\mathrm{Al}, \mathrm{Mg})_{\mathrm{x}} \mathrm{O}(\mathrm{Mg}$ はるつ涪から混入した不純物 $)$ が析出物の優先析出核として作用し, $\mathrm{MgS}, \mathrm{Al}(\mathrm{N}, \mathrm{S})$ の生成を 促進して, 固溶 Sを減少させ, その結果, S の粒界への偏析 を抑制することを示唆している.

Takamura と Mizoguchi ${ }^{(6)}$ はオキサイドメタラジーの概念と して, 酸化物粒子が陽イオン空孔を含む場合には, その陽イオ ン空孔を介し地鉄中の金属元素が拡散浸透し，局部的に原子結 合が形成され，その結果，この酸化物粒子が析出物の優先析出 核となることを提言している. この原理によれば, 酸素イオン 空孔を含むコランダム構造をもつ $\mathrm{Al}_{2} \mathrm{O}_{3}$ 単独では硫化物等の 優先析出核とはなり得ない。しかし，本報で観察された $(\mathrm{Al}$, $\mathrm{Mg})_{\mathrm{x}} \mathrm{O}$ の場合は, 硫化物の析出核として機能することが可能 となる.すなわち, $\mathrm{MgO}$ と $\mathrm{Al}_{2} \mathrm{O}_{3}$ とはスピネル構造の固溶体 として $\mathrm{MgO} \cdot \mathrm{Al}_{2} \mathrm{O}_{3}-\mathrm{Al}_{2} \mathrm{O}_{3}$ を生成するといわれ(10)，また $\mathrm{MgO}$ の 2 価の $\mathrm{Mg}^{+2}$ $\mathrm{Al}_{2} \mathrm{O}_{3}$ の 3 価の $\mathrm{Al}^{+3}$ が置換すれば, $\mathrm{MgO}$ には陽イオン空孔が形成される. したがって, 本研究の場合, $\mathrm{Mg}$ は意図的には添加していないが，Al 添加によりマグネシ アるつぼから還元され溶鉄に混入した $\mathrm{Mg}$ と，すでに溶鉄中 に生成している $\mathrm{Al}_{2} \mathrm{O}_{3}$ とが反応し, $\mathrm{Al}_{2} \mathrm{O}_{3}$ の外郭に陽イオン空 孔を含むスピネル酸化物 $\mathrm{MgO} \cdot \mathrm{Al}_{2} \mathrm{O}_{3}$ を生成したものと考兄ら れる. その後の熱処理過程で, この酸化物中の陽イオン空孔を 介し, $\mathrm{Mg}^{+2}$ と $\mathrm{Al}^{+3}$ が粒子の表面へ拡散し, これらの陽イオ 
ンと $\mathrm{S}, \mathrm{N}$ とがこの粒子界面で化合し, $\mathrm{MgS}, \mathrm{Al}(\mathrm{N}, \mathrm{S})$ を核生 成したものと考えられる.

本研究で観察した $(\mathrm{Al}, \mathrm{Mg})_{\mathrm{x}} \mathrm{O}$ がスピネル構造の $\mathrm{MgO}$. $\mathrm{Al}_{2} \mathrm{O}_{3}$ であるかはまだ確認できていないが， $\mathrm{AES}$ 観察に打け るこの $(\mathrm{Al}, \mathrm{Mg})_{\mathrm{x}} \mathrm{O}$ からの $\mathrm{Al}$ ピーク形状(Fig. 12, (a)-1)はコ ランダム構造の $\mathrm{Al}_{2} \mathrm{O}_{3}$ から得られたもの(7) とは明らかに異な ることから, 少なくとも $\mathrm{Al}_{2} \mathrm{O}_{3}$ 単独とは異なる別の $\mathrm{Al}$ 系酸化 物であることは明らかである。

\section{2. $\mathrm{Mn}, \mathrm{Ca}, \mathrm{Ti}$ 系酸化物の影響}

$\mathrm{Mn}, \mathrm{Ca}, \mathrm{Ti}$ は陽イオン空孔型酸化物生成元素であると同時 に硫化物生成元素でもある.

たとえば，Mn は容易に硫化物を生成し固溶 S を固定する. 本研究に用いた試料には Mn 無添加材にも不純物として最大 で $0.004 \mathrm{mass} \%$ のn が含まれ，この $\mathrm{Mn} か ゙ \mathrm{MnS}$ を生成す ると仮定すれば化学量論的には $0.002 \mathrm{mass} \%$ の固溶 $\mathrm{S}$ が固定 されたことになる。. しかしながら，Mn, O, S の複合体と見ら れる $\mathrm{Mn}$ の化合物は $\mathrm{Mn}$ 添加材 $(2 \mathrm{CMnP})$ 飞未いてのみ確認さ れている(Fig. 9). 前述の $(\mathrm{Al}, \mathrm{Mg})_{\mathrm{x}} \mathrm{O}$ の場合に準じて推論す れば，酸素濃度の高い溶鉄に Mn を添加した場合には，まず $\mathrm{MnO}$ が形成され，( $\mathrm{Al}, \mathrm{Mg})_{\mathrm{x}} \mathrm{O}$ の場合と同様に $\mathrm{MnO}$ 中の $\mathrm{Mn}^{2+}$ イオンの外方拡散により $\mathrm{MnO}$ 表面に $\mathrm{MnS}$ が形成され る可能性がある.

$\mathrm{Ca}$ 添加材に招いては，Ca 酸化物個数は酸化物総数の括上そ 3 分の 1 であり (Fig. 9), これらの Ca 酸化物には S が重畳し ている. $\mathrm{Ca}$ 添加試料 $2 \mathrm{CCaP}$ の $\mathrm{Ca}$ 含有量は微量であり固溶 $\mathrm{S}$ を $\mathrm{CaS}$ として固定するには化学量論的には不十分である。そ れにもかかわらずSをほとんど完全に固定する機構について は不明であるが，その一端を説明し得るものとしてつぎのよう に考えられる. Ca が微量で効果を発揮しているのは, 酸化物 粒子の最外郭のみに陽イオン空孔型の $\mathrm{Ca}$ 酸化物を形成し有効 表面積を大きくしていることが考兄られる(中央部は $\mathrm{Si}$ 系酸化 物が多い).この複合酸化物が $\mathrm{Al}$ 添加の場合と同様な機構で 硫化物の優先析出核サイトとして機能するものとみられる.さ らに Ca と S は化学的な親和力が強いので $\mathrm{Ca}$ 酸化物界面に多 くのSを偏析させることも考えられるまをた，酸化物上には リン化物子複合析出して括り, Ca 酸化物は固溶 $\mathrm{S}$ と $\mathrm{P}$ 同時 に結晶粒内に固定できることを示唆している.

$\mathrm{Ti}$ 添加材に执いては，溶鉄に Ti を添加した際，酸素と結合 して浮上除去されたので, Ti 酸化物とみられる粒子個数は少 ない(Fig. 9)。この場合も， $\mathrm{Ti}$ 酸化物が $\mathrm{TiO}$ あるいは $\mathrm{Ti}_{2} \mathrm{O}_{3}$ であれば陽イオン空孔型酸化物であり, $(\mathrm{Al}, \mathrm{Mg})_{\mathrm{x}} \mathrm{O}$ の場合と 同様にして $\mathrm{S}$ を，さらには $\mathrm{P}$ を固着する可能性がある.

\section{3. $\mathrm{FeO}$ と $\mathrm{S}$ の粒界偏析}

酸素含有量の多い電解鉄を素材として溶製した本研究の試料 には，多数の $\mathrm{FeO}$ が生成している(Fig. 10)。 また C 含有量の 増加により, 溶製中の脱酸効果により酸化物粒子数は減少する

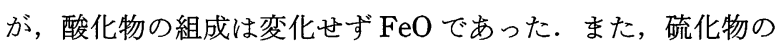
生成も認められず, $\mathrm{Fe}$ と O 和よび S は同一粒子から検出され ることもなかった。これらのことからみて, 晶出した $\mathrm{FeO}$ は, $(\mathrm{Al}, \mathrm{Mg})_{\mathrm{x}} \mathrm{O}$ とは異なり硫化物の優先析出や $\mathrm{S}$ を固溶する機能
をもたないことになる。この場合， $\mathrm{FeO}$ は $(\mathrm{Al}, \mathrm{Mg})_{\mathrm{x}} \mathrm{O}$ と同様 に陽イオン空孔を含む酸化物であり, $\mathrm{Fe}^{2+}$ の拡散は可能では ある.しかし， $\mathrm{FeO}$ の周辺はすべて $\mathrm{Fe}$ マトリックスであり $\mathrm{FeS}$ を形成するとしても $\mathrm{FeO}$ 中の $\mathrm{Fe}^{2+}$ の拡散は不要であり， しかも $\mathrm{Fe}$ と $\mathrm{S}$ と結合力が弱いため $\mathrm{FeO}$ を核にした $\mathrm{S}$ の固 着が生じないものと考觉られる.

\section{4. 粒界脆化に及ばす $\mathrm{S}$ の影響}

B は添加していないが全試料に不純物としてのBが含有さ れて和り, $\mathrm{Al}$ 添加材 (2CA11)の粒界には 1.3 at.\%のB が偏析 していた. 周知のごとく，鉄中での B は BN として固定され 易い. しかし，Al 添加により $\mathrm{N}$ が $\mathrm{AlN}$ として完全に固定され， $\mathrm{BN}$ の生成が阻止されれば，大部分の B が固溶 B となる。つ まり，このような現象が起こる $\mathrm{Al}$ 添加材の場合についてのみ $\mathrm{B}$ の粒界偏析が可能となる。この粒界偏析 B は P の粒界偏析 を低減する効果があるといわれて扣り(11)，S の粒界偏析に対し ても同様な効果があると仮定し，加えて，粒界偏析 B による 粒界結合力の増加(12)を考慮すれば，Bによる粒界脆化防止機 能も考兄られる. Liu ら ${ }^{(12)}$ は高純度鉄に打いて，B抽よび C の粒界偏析量 1 at.\%の増加によりFATT が各々 $20 \mathrm{~K}, 10 \mathrm{~K}$ 低下する結果を示している。この粒界偏析 B および C 量と FATT の関係を用い，基準となる 0.002 mass $\% \mathrm{C}$ 試料と $\mathrm{Al}$ 添加試料に抢ける B, C, S の粒界偏析濃度 (Fig. 6) から Al 添加 材での粒界偏析 B， C, S が FATT に及ぼすそれぞれの寄与に ついて概算してみた。ここで， $\mathrm{Al}$ 添加により粒界偏析 B は 1.3 at.\%, C は 1.7 at.\%, 各々増加する. 一方, 粒界偏析 S は 4.7 at.\%だけ低減する。これらの值から Al 添加に抢ける粒界 偏析 B とCによるFATT の低下幅を求めると，それぞれ B により $23 \mathrm{~K}, \mathrm{C}$ にり $17 \mathrm{~K}$ であり，合計 $40 \mathrm{~K}$ となる。 また， $\mathrm{Al}$ 添加による FATT の低下幅は $240 \mathrm{~K}$ であるので, C, B の 粒界偏析による FATT の低下幅 $40 \mathrm{~K}$ を差し引いた $200 \mathrm{~K}$ が 粒界偏析 S 量 4.7 at.\%の低減による FATT の低下幅である. これから粒界偏析 S の 1 at.\%の低減により FATTは $43 \mathrm{~K}$ 低 下することが分かる．概算ではあるが，この結果から本研究に 扣いて， $\mathrm{Al}$ 添加による FATT の低下は $(\mathrm{Al}, \mathrm{Mg})_{\mathrm{x}} \mathrm{O}$ の形成に より生じた粒界偏析 S の低減による寄与が大きいと推論され る.

\section{V. 結 言}

電解鉄ベースの純鉄 (C 含有量 $0.002,0$ 含有量 $~ 0.015, \mathrm{~S}$ 含有量～ 0.006 mass\%) に执いて, S に上る粒界脆化は微量の 脱酸元素 $(\mathrm{Mn}, \mathrm{Al}, \mathrm{Ca}, \mathrm{Ti})$ の添加により改善される. 本研究で はこの機構解明を目的とし, 粒界破面の表面分析执よび酸化 物, 硫化物の同定などを行い, 各種酸化物が不純物元素の粒界 偏析に及ぼす影響を検討した。得られた結果を以下に要約す る.

（1）不純物として含まれるSがフェライト粒界に偏析し， 著しい粒界脆化を生じる. 微量の $\mathrm{C}$ および $\mathrm{Al}$ 添加等による脆 化の改善はいずれも S の粒界偏析の抑制に起因している.

(2) $\mathrm{Al}$ 添加による S の粒界偏析の抑制効果は, 溶鉄中に晶 出した $\mathrm{Al}_{2} \mathrm{O}_{3}$ と不純物として混入した $\mathrm{Mg}$ が反応して生成し 
た $(\mathrm{Al}, \mathrm{Mg})_{\mathrm{x}} \mathrm{O}$ にSが固定されることによって生じる。この $(\mathrm{Al}, \mathrm{Mg})_{\mathrm{R}} \mathrm{O}$ は陽イオン空孔型の酸化物で，この空孔を介し酸 化物内の $\mathrm{Mg}^{2+}$ と $\mathrm{Al}^{3+}$ 愔粒子界面へ拡散し, 同時に母相加ら その界面へ偏析してくる $\mathrm{S}, \mathrm{N}$ と化合し, 粒子上に $\mathrm{MgS}$, $\mathrm{Al}(\mathrm{N}, \mathrm{S})$ を優先核生成させるるのと推論でさる。

(3) $\mathrm{Mn}, \mathrm{Ca}, \mathrm{Ti}$ む陽イオン空孔型酸化物を形成するので, これらの元素の添加による $\mathrm{S}$ 粒界偏析抑制の効果についても， $(\mathrm{Al}, \mathrm{Mg})_{\mathrm{x}} \mathrm{O}$ の場合と類似の機構が考克られる.すすなる，鉄 中火分散晶出した，これらの陽イオン型酸化物 $(\mathrm{MnO}, \mathrm{CaO}$, $\left.\mathrm{TiO}, \mathrm{Ti}_{2} \mathrm{O}_{3}\right)$ は硫化物の優先析出核として機能する可能性を米 つ. また Mn, Ca, Ti のリン化物る知られているので, Sの場 合と同様に P を固定する効果も想定できる.

(4) $\mathrm{FeO}$ す陽イオン空孔型であるが， $\mathrm{FeO}$ は硫化物の優先

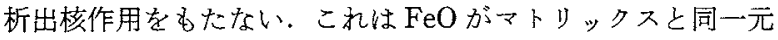
素であり，FeOの存在はマトリックスの Fek対し何らかの特 異性をるたないためと考光られる。

(5) C 添加による S の粒界偏析抑制は上述の機構とは異な り，粒界に持けるSとCの site competition 機構(3)で説明で きる.な执，粒界脆化の軽減については， S の粒界偏析の㧕制 飞加光， C, B の粒界結合力の堌加の効果も寄与しているもの とみられる ${ }^{(12)}$.

最後に，本実験結果がオキサイド・メタラジーの概念により 説明可能でするとの有益な御助言を賜った京都大学名誉教授、
故 高村仁一博士に深く感謝の意を表します。また，酸化物， 析出物の電子線回折にご助力いただいた，新日本製鐵侏先端技 術研究所・船木秀一氏㴬意を表します。

\section{文献}

（1）木村 宏：日本金属学会会報，24(1985)，376。

(2) P. Jolly and C. Goux: Mem. Sci. Rev. Met., 66(1969), No. 9, 605 .

(3) S. Suzuki, K. Abiko S. Tanii and H. Kimura: Met. Trans., 18A (1987), 1109.

（4）武智 宏 : 日本金属学会会報，30(1991)，677.

(5) N. Takahashi, M. Shibata, Y. Furuno, H. Hayakawa, K. Kakuta and $\mathrm{K}$. Yamamoto: Proc. of Conf. on Metallurgy of Continuous-Annealed Sheet Steel, AIME, (1982), 133.

(6) J. Takamura and S. Mizoguchi: Proc. 6th Int. Iron and Steel Congress, Nagoya, 1(1990). 591 [ISIJ].

(7) P. W. Palmberg, G. E. Riach, R. E. Weber and N. C. MacDonald: Handbook of Auger Electron Spectroscopy, Physical Electronics Industries Inc., (1972).

(8) J. R. Rellik and C. J. Mcmahon, Jr.: Met. Trans., $1(1970), 929$.

（9）第 3 版鉄鋼便覧 I，鉄鋼協会編，(1981)，11

(10) A. M. Alper, R. N. Mcnally, P. G. Ribbbe and R. C. Doman: J. Am. Ceram. Soc., 45[6](1962), 264.

(11) C. M. Liu, T. Nagoya, K. Abiko and H. Kimura: Met. Trans., 23A (1992), 263.

(12) C. M. Liu, K. Abiko and H. Kimura: Met. Trans., 23A(1992), 1515. 